\title{
INNOVATIVE TECHNOLOGIES FOR THE PRODUCTION OF ELASTIC LEATHER MATERIALS
}

\author{
A. Danylkovych, S. Bilinskii \\ Kyiv National University of Technologies and Design
}

\begin{tabular}{l}
\multicolumn{1}{c}{ Key words: } \\
Industrial approbation \\
Technological processes \\
Filling-retanning \\
Semi-finished chrome \\
Tanning product \\
Production of elastic \\
leather \\
Physicochemical \\
properties \\
\hline \multicolumn{1}{c}{ Article history: } \\
Received 06.11.2018 \\
Received in revised form \\
23.11.2018 \\
Accepted 18.12.2018 \\
\hline
\end{tabular}

Corresponding author:
A. Danylkovych
E-mail:
npnuht@ukr.net

\begin{abstract}
For the industrial approbation of the developed biotechnologies, using the chrome tanning semi-finished product of wet-salted raw material of cattle - heavy heifer, bulls, and outgrowths thickness respectively by $1.7,1.5$ and $1.4 \mathrm{~mm}$. The filling-retanning processes were carried out in a "Doze" company drum (Germany) with a volume of $0.39 \mathrm{~m}^{3}$ at a temperature of $30-32^{\circ} \mathrm{C}$, mixing with its $7-8 \mathrm{~min}^{-1}$ rotation speed and using ionized nanosilica A-300.

The use of ionized nanosilica A-300 by 1 technology provides a reduction in the consumption of imported materials through the formation of increased volumetric output and adhesion in leather material, respectively, by $13 \%$ and $19-26 \%$ compared with the material obtained by the current technology. The use of the biocatalytic modifier in 2 technology make it possible to reduce the consumption of imported reagents by $38 \%$ with an increase in the elasticplastic parameters of the leather material, in particular, increase the breaking elongation to $77 \%$. At the same time, the output area of leather material is increase and achieved by $5.1 \%$. According to 3 technology, complete replacement of the quiberacho extract with a nanocrystalline A-300 ensures the formation of light-colored leather with a topographically more homogeneous with an output area increased by $3.7 \%$.

The complex of physico-mechanical properties of the resulting leather is dominated by industrially manufactured and meets the requirements for elastic leather for garments in accordance with DSTU 3115-95 and the international standard ISO 9001:2015 "Quality management systems. Requirements". Manufacturing on the developed technologies for the formation of chrome-tanning elastic leather materials are patented and can be considered as promising for the introduction of tanneries into the industry.
\end{abstract}

DOI: $10.24263 / 2225-2924-2018-24-6-6$ 


\title{
ІННОВАЦІЙНІ ТЕХНОЛОГІЇ ВИРОБНИЦТВА ЕЛАСТИЧНИХ ШКІРЯНИХ МАТЕРІАЛІВ
}

\author{
А.Г. Данилкович, С.О. Білінський \\ Київський національний університет технологій та дизайну
}

Для промислової апробачії розроблених технологій використаний напівфабрикат хромового дублення мокросоленої сировини великої рогатої худоби яловиці важкої, бичини і виростка товщиною, відповідно, 1,7, 1,5 i 1,4 мм. Наповнювально-додублювальні прочеси проводили у барабані фірми Dоzе (Німеччина) об' ємом 0,39 $\mathrm{m}^{3}$ за температури 30-32 ${ }^{\circ} \mathrm{C}$ при перемішуванні за швидкості його обертання 7-8 хв ${ }^{-1}$ та використанні йонізованого нанокремнезему $A-300$.

Використання йонізованого нанокремнезему A-300 за технологією 1 забезпечує зменшення витрат імпортних матеріалів завдяки формування шкіряного матеріалу з підвищеними об'ємним виходом і адгезією, відповідно, на 13\% і 19-26\% порівняно з матеріалом, отриманим за діючою технологією. Використання біокаталітичного модифікатора в технології 2 дало можливість скоротити витрати імпортних реагентів на $38 \%$ при підвищенні пружно-пластичних показників шкіряного матеріалу, зокрема розривного видовження до 77\%. При изьому досягається збільшення виходу площі шкіряного матеріалу на 5,1\%. Повна заміна екстракту квебрахо нанокремнеземом A-300 за технологією 3 забезпечує формування шкір світлих кольорів топографічно більи однорідних з підвищенням виходу площі на 3,7\%.

За комплексом фізико-механічних властивостей отримані икіри переважають промислово виготовлені й відповідають вимогам щзодо еластичних шкір для швейних виробів за ДСТУ $3115-95$ та міжнародного стандарту ISO 9001:2015 «Системи управління якістю. Вимоги». Виготовлення шкіряних матеріалів за розробленими технологіями формування еластичних шкіряних матеріалів хромового дублення патентнообгрунтовані й можуть розглядатись як перспективні для впровадження на підприємствах шкіряного виробництва.

Ключові слова: промислова апробачія, технологічні прочеси, наповнювання-додублювання, напівфабрикат хромового дублення, виробництво еластичних шкір, фізико-хімічні властивості.

Постановка проблеми. Високоефективні технології виробництва різноманітної продукції відзначаються економічністю, масо- і енергозатратністю, високою екологічністю. Значною мірою це стосується виробництва натуральних шкіряних матеріалів, яке характеризується дефіцитністю і різноманітністю білкової сировини, тривалістю технологічних процесів, сучасними вимогами до якості та асортименту шкіряних матеріалів. Одним із варіантів вирішення цієї проблеми $є$ розроблення високопродуктивних технологій 3 використанням нових хімічних реагентів і матеріалів, які дають можливість замінити дефіцитні імпортні. При цьому з'являється можливість розширити асортимент існуючої шкіряної продукції, в тому числі шкіряних матеріалів 
світлих кольорів. Враховуючи велику роль післядубильних процесів при формуванні структури і властивостей еластичних шкіряних матеріалів у технологічному циклі їх виробництва, значна увага при розробленні нових технологій приділяється процесам наповнювання-додублювання структурованого напівфабрикату.

У технологічних процесах виробництва натуральних матеріалів хромового дублення із сировини шкур великої рогатої худоби використовується велика кількість хімічних реагентів і матеріалів, зокрема природних і синтетичних структуруючих реагентів, у тому числі екстрактів рослинних матеріалів, дисперсій акрилових полімерів, а також бентоніту, каоліну, тальку тощо $[1 ; 2]$. Також використовуються композиції, що включають природні та синтетичні реагенти. Слід зазначити, що в [2] для формування об'єму і виходу площі натурального матеріалу рекомендується використовувати алюмосилікати. Завдяки модифікації поверхні частинок суспензій мінералів реалізується висока їх дисперсність.

Досліджені процеси наповнювання-додублювання напівфабрикату хромового дублення з використанням танідів мімози з оксазолідином [3]. Показана ефективність такого підходу при формуванні фізико-хімічних і технологічних властивостей шкір з урахуванням їх асортименту. Авторами [4] досліджено вплив дисперсій бутилакрилату й етилакрилату на процес формування шкір. Встановлено їх позитивний вплив на пружно-пластичні властивості матеріалу. У [5] встановлено вплив ферментно-модифікованих наповнювачів на властивості шкір світлих кольорів. Отримані шкіри характеризувались підвищеними органолептичними властивостями порівняно 3 контрольними. При використанні композиції високодисперсного оксиду кремнію (IV) і оксазолідину [6] показано підвищення стійкості натурального матеріалу до бактеріальної дії.

Отже, тільки композиції природних і синтетичних наповнювально-додублювальних реагентів можуть забезпечити ефективне формування структури шкіряного напівфабрикату та дифузійної здатності його лицьового шару щодо оздоблювальної композиції.

Мета дослідження: апробація розроблених технологій із скороченням витрат імпортних хімічних реагентів завдяки застосуванню нанокремнезему А-300, застосуванням біокаталітичного модифікатора (БКМ) на стадії попередньої пластифікації напівфабрикату хромового дублення, повної заміни забарвлених інгредієнтів нанокремнеземом А-300 при виготовленні шкір світлих кольорів.

Матеріали і методи. Для промислової апробації розроблених технологій наповнювання-додублювання використаний напівфабрикат хромового дублення мокросоленої сировини великої рогатої худоби різної маси і товщини. У технології із зменшеною витратою хімічних реагентів (технологія 1 ) $[7 ; 8]$ обробленню підлягав напівфабрикат, отриманий із сировини яловиці важкої товщиною 1,5 мм. При апробації технології наповнювання-додублювання шкіряного напівфабрикату з попередньою пластифікацією (технологія 2) [9] використано напівфабрикат із сировини бичка товщиною 1,7 мм. У технології 3 повною заміною танідів нанокремнеземом А-300 (технологія 3) [10] засто- 
совано напівфабрикат із сировини виростка товщиною 1,4 мм. Витрати реагентів при реалізації розроблених технологій наведені в табл. 1.

Таблиия 1. Витрати реагентів

\begin{tabular}{|c|c|c|c|c|c|}
\hline \multirow{2}{*}{ Реагент } & \multirow{2}{*}{ Країна } & \multicolumn{4}{|c|}{ Витрата реагентів маси } \\
& & напівфабрикату, \%, за технологією \\
\cline { 3 - 6 } & & 1 & 2 & 3 & діюча \\
\hline Нанокремнезам A-300 & Україна & 1,8 & 1,0 & 2,5 & - \\
Модифікатор БКМ [11] & Україна & - & 0,2 & - & - \\
Дисперсія Relugan D & Німеччина & 1,5 & - & - & 2,0 \\
Дисперсія Trupotan G & Німеччина & 2,25 & 2,0 & - & 3,0 \\
Жирувальний реагент Trupol DL & Німеччина & 6,0 & 6,0 & 8,2 & 7,0 \\
Дисперсія Retanal RCN-40 & Іспанія & - & - & 6,3 & - \\
Екстракт квебрахо & Китай & 5,45 & 5,0 & - & 6,0 \\
Алюмокалієвий галун & Україна & 5,0 & 5,0 & 5,0 & - \\
Мурашина кислота & Україна & - & - & - & 0,4 \\
\hline
\end{tabular}

Білкова сировина до наповнювально-додублювальних процесів готувалась за діючою технологією виробництва еластичних шкір на ПАТ «Чинбар», яка включала гідролітичне відновлення структури шкіряної сировини, лужне зневолошування і зоління, знезолювання-м'якшення, кислотно-сольове пікелювання, дублення сполуками хрому (III), віджимання напівфабрикату та його стругання на задану товщину. Ці процеси виконувались у барабані фірми Olcina (Іспанія).

Наступні наповнювально-додублювальні процеси проводили у барабані фірми Doze (Німеччина) об'ємом 0,39 м $^{3}$ за температури $30-32^{\circ} \mathrm{C}$ при перемішуванні за швидкості його обертання $7-8$ хв $^{-1}$. Процес завершували обробленням напівфабрикату алюмокалієвим галуном і промиванням. Оздоблювання отриманого шкіряного напівфабрикату проводили після виконання сушильно-зволожувальних процесів і операцій 3 використанням матеріалів композиції BASF (Німеччина) за технологією, наведеною в табл. 2.

Таблиця 2. Технологія оздоблювальних процесів і операцій

\begin{tabular}{|c|c|c|}
\hline \begin{tabular}{|c|} 
Поточне \\
число
\end{tabular} & $\begin{array}{l}\text { Процес, } \\
\text { операція }\end{array}$ & $\begin{array}{l}\text { Склад композиції, мас. \%, іiї витрати } \\
\text { та режим оброблення }\end{array}$ \\
\hline 1 & 2 & 3 \\
\hline \multirow[t]{2}{*}{1} & \multirow[t]{2}{*}{$\begin{array}{l}\text { Нанесення } \\
\text { грунту }\end{array}$} & $\begin{array}{c}\text { Пігментний концентрат Lepton Farben N } \\
\text { чорно-фіолетовий чи білий - } 100 \\
\text { Lepton Filler K - } 80 \\
\text { Lepton Wachs A - } 30 \\
\text { Вода }-270 \\
\text { Corial Binder DN }-150 \\
\text { Corial Binder OT }-180\end{array}$ \\
\hline & & $\begin{array}{c}\text { Розпилювальний агрегат для покривного фарбування. Грунт } \\
\text { наносять у } 2 \text { проходи з витратою } 60-70 \text { г/м }\end{array}$ \\
\hline 2 & Пресування & $\begin{array}{c}\text { Гідравлічний прес з гладкою або пилоподібною плитою чи } \\
\text { валковий прохідний прес. Температура } 65+5^{\circ} \mathrm{C} ; \\
\text { тиск для гідравлічного пресу } 15+1 \mathrm{MПа,} \\
\text { для прохідного валкового пресу } 3+1 \mathrm{MПа}\end{array}$ \\
\hline
\end{tabular}


БІОТЕХНОЛОГЇ̈

\begin{tabular}{|c|c|c|}
\hline & & Продовження табл. 2 \\
\hline 1 & 2 & 3 \\
\hline \multirow[t]{3}{*}{3} & \multirow[t]{3}{*}{$\begin{array}{l}\text { Нанесення } \\
\text { покривної } \\
\text { фарби }\end{array}$} & $\begin{array}{c}\text { Пігментний концентрат Лептон } \mathrm{N}-100 \\
\text { Lepton Wachs } \mathrm{A}-30 \\
\text { Lepton Filler K }-80 \\
\text { Вода }-340\end{array}$ \\
\hline & & $\begin{array}{l}\text { Corial Binder OT }-120 \\
\text { Lepton Binder LF }-100\end{array}$ \\
\hline & & $\begin{array}{c}\text { Розпилювальний агрегат } \\
\text { для покривного фарбування. Композицію наносити } \\
\text { в } 2 \text { проходи для шкір темних забарвлень } \\
\text { i в } 3 \text { проходи для світлих кольорів за витрат фарби } 60-90 \text { г/м² }\end{array}$ \\
\hline 4 & $\begin{array}{c}\text { Вібраційно- } \\
\text { витягувальне } \\
\text { оброблення }\end{array}$ & $\begin{array}{c}\text { Проводять на прохідній витягальній машині } \\
\text { по всій площі. Швидкість транспортування напівфабрикату } \\
16-26 \text { см /сек, глибина заходу кілків машини - } 7 \text { мм. }\end{array}$ \\
\hline \multirow{2}{*}{5} & \multirow{2}{*}{$\begin{array}{l}\text { Нанесення } \\
\text { першого } \\
\text { закріплення }\end{array}$} & $\begin{array}{l}\text { Corial EM Finish ES - } 100 \\
\text { Вода }-100\end{array}$ \\
\hline & & $\begin{array}{r}\text { Розпилювальний агрегат. Закріплювальний склад наноситься за } \\
1 \text { прохід з витратою } 40-45 \text { г/м² }\end{array}$ \\
\hline 6 & Пресування & $\begin{array}{c}\text { Гідравлічний прес з гладкою плитою } \\
\text { або валковий прохідний прес. Температура }-70+5^{\circ} \mathrm{C} . \\
\text { Тиск: для гідравлічного пресу } 10+1 \mathrm{MПа}, \\
\text { для прохідного валкового пресу } 3+1 \mathrm{MПа.} \\
\text { Допускається заключне пресування } \\
\text { після другого закріплення } \\
\end{array}$ \\
\hline \multirow{2}{*}{7} & \multirow{2}{*}{$\begin{array}{l}\text { Нанесення } \\
\text { другого } \\
\text { закріплення }\end{array}$} & $\begin{array}{l}\text { Corial EM Finish ES - } 100 \\
\text { Вода }-100\end{array}$ \\
\hline & & \begin{tabular}{|c|} 
Розпилювальний агрегат. Закріплювальний склад наноситься за \\
1 прохід 3 витратою $45+5$ г/м² \\
\end{tabular} \\
\hline 8 & Обрізування & $\begin{array}{c}\text { Бахрома і непридатні крайові ділянки обрізуються } \\
\text { електроножицями }\end{array}$ \\
\hline 9 & $\begin{array}{l}\text { Вимірювання } \\
\text { площі }\end{array}$ & Площу вимірюють на прохідних машинах \\
\hline
\end{tabular}

Фізико-хімічні дослідження оздоблених шкір проводили після кондиціювання відібраних зразків за нормальних умов [12]. Фізико-механічні випробування виконували на машині РТ-250М при швидкості деформування зразків $0,09 \mathbf{M}^{\prime} \mathbf{B}^{-1}$. Жорсткість шкіри вимірювали на приладі ПЖУ-12М.

Викладення основних результатів дослідження. Результати дослідження фізико-хімічних властивостей шкір хромового дублення за розробленими технологіями наповнювання-додублювання наведені на рисунку і табл. 3 - 6 . Зменшення витрат імпортних реагентів за технологією 1 порівняно $з$ діючою технологією на, \%: екстракту квебрахо - 10, дисперсій Relugan D i Trupotan $\mathrm{G}-33$ та жирувального матеріалу Trupol DL - 16\% за рахунок використання нанокремнезему A-300 - 1,8\% дає можливість одержати натуральний матеріал з підвищеним об'ємним виходом і пористістю відповідно на 13 і $11 \%$ (рисунок). При цьому отримані шкіри дещо міцніші з вищим видовженням при навантаженні 10 МПа та розривним (табл. 3). Одночасно збільшується адгезія покриття до сухої і мокрої шкіри на 19 і 26\%. 

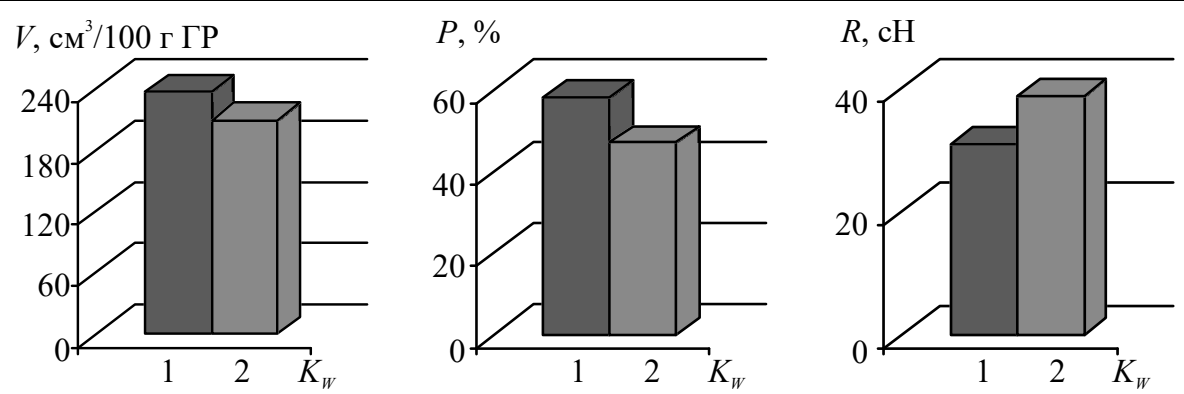

Рис. Залежність властивостей шкіряного матеріалу від складу композиції: 1 - розробленої, 2 - діючої технології;

$a$ - об'ємний вихід, б- пористість, в - жорсткість

Таблиия 3. Фізико-механічні властивості шкіряного матеріалу, отриманого за технологісю 1

\begin{tabular}{|c|c|c|}
\hline Показник & \multicolumn{2}{|c|}{ Технологія } \\
\cline { 2 - 3 } & 1 & діюча \\
\hline Температура зварювання напівфабрикату, ${ }^{\circ} \mathrm{C}$ & 113,0 & 112,4 \\
Товщина шкіри, мм & 1,35 & 1,29 \\
Межа міцності при розтягуванні, МПа & 28,5 & 27,0 \\
Відносне видовження при навантаженні $10 \mathrm{MПа,} \mathrm{\%}$ & 30,0 & 27,0 \\
Відносне видовження при розриві, \% & 62,5 & 58,0 \\
Маса покривної плівки, г/м ${ }^{2}$ & 71,5 & 73,1 \\
Адгезія покриття, Н/м, до сухої шкіри & 1024 & 860 \\
- до мокрої шкіри & 520 & 410 \\
Стійкість покриття до мокрого тертя, оберти & 320 & 290 \\
- до багаторазового вигинання, тис. вигинів & 23,5 & 19,0 \\
\hline
\end{tabular}

Позитивний вплив розробленого складу наповнювально-додублювальної композиції може бути зумовлений глибокою міжфібрилярною дифузією частинок нанокремнезему A-300 в структуру шкіряного напівфабрикату та рівномірнішим розподілом іiі інгредієнтів в мікроструктурі матеріалу. Після видалення з матеріалу вологи наявність нанокремнезему А-300 в міжфібрилярних проміжках з пластифікатором Trupol DL забезпечує збереженість мобільності всієї структури волокнистого матеріалу та підвищення його еластичності.

Розроблена технологія 2 завдяки використання БКМ дає можливість скоротити витрати імпортних матеріалів на $38 \%$. Як свідчать отримані дані (табл. 4), шкіряний напівфабрикат, одержаний за розробленою технологією, має меншу жорсткість і більше відносне видовження при навантаженні $10 \mathrm{MПа}$ відповідно на 33 і 77\% порівняно 3 діючою технологією. При цьому досягається вищий об'ємний вихід матеріалу. В той час як за міцністю і відносним видовженням при розриві сформований матеріал відповідає одержаному за діючою технологією.

Незначне зменшення товщини покривної полівки порівняно 3 промисловою технологією зумовлено дещо більшою всмоктувальною здатністю лицьового шару шкіряного напівфабрикату внаслідок зниження щільності 
його структури, одержаного за розробленою технологією 2. У зв'язку з цим спостерігається підвищення адгезії покриття отриманого матеріалу як у сухому, так і мокрому стані, що викликано ефективнішою взаємодією інгредієнтів грунту з модифікованим аеросилом колагеном дерми. Особливо це стосується адгезії покриття у мокрому стані, яка на $28 \%$ є вищою порівняно із сухим станом шкіри. Зростання стійкості покриття до мокрого тертя насамперед зумовлено підвищенням його пружно-пластичних властивостей. У зв'язку зі зменшенням товщини покривної плівки і меншим рівнем внутрішніх напружень на $24 \%$ зростає опір покриття до багаторазового вигинання.

Таблиця 4. Фізико-механічні властивості шкіряного матеріалу, отриманого за технологією 2

\begin{tabular}{|c|c|c|}
\hline \multirow{2}{*}{ Показник } & \multicolumn{2}{|c|}{ Технологія } \\
\hline & 2 & діюча \\
\hline Температура зварювання напівфабрикату, ${ }^{\circ} \mathrm{C}$ & 113,0 & 111,0 \\
\hline Об'ємний вихід шкіри, см³/100 г ГР & 239,0 & 227,0 \\
\hline Пористість зразків, \% & 55,0 & 49,0 \\
\hline Повітропроникність, $\mathrm{cm}^{3} / \mathrm{cm}^{2} \cdot$ год. & 249,0 & 237,0 \\
\hline Межа міцності при розтягуванні, МПа & 22,5 & 21,3 \\
\hline Відносне видовження при навантаженні 10 МПа, \% & 37,3 & 21,0 \\
\hline Відносне видовження при розриві, \% & 60,0 & 57,0 \\
\hline Жорсткість шкіряного напівфабрикату, сH & 21,0 & 28,0 \\
\hline 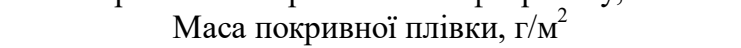 & 70,4 & 72,9 \\
\hline Адгезія покриття, Н/м, до сухої шкіри & 1096 & 830 \\
\hline - до мокрої шкіри & 527 & 390 \\
\hline Стійкість покриття до мокрого тертя, оберти & 330 & 300 \\
\hline - до багаторазового вигинання, тис. вигинів & 33,0 & 24,0 \\
\hline Вихід шкіряного матеріалу, \% & 105,1 & 100,0 \\
\hline
\end{tabular}

Введення в шкіряний напівфабрикат нанокремнезему після попередньої пластифікації його структури біокаталітичним модифікатором сприяе збільшенню виходу площі матеріалу на 5,1\% порівняно 3 діючою технологією. Цей ефект може бути обумовлений вищим ступенем орієнтації елементів волокнистої структури шкіряного матеріалу завдяки попередній його пластифікації та наступної фіксації при термомеханічному обробленні на розвідній машині.

Водночас дифузія грунту в попередньо пластифікований ензимною обробкою шкіряний напівфабрикат сприяє формуванню дещо меншої товщини покривної плівки i, відповідно, зростанню ії адгезії до сухої і мокрої шкіри та опору покриття до багаторазового вигинання. Високоеластичність отриманого шкіряного матеріалу зумовлена комплексом високих пружно-пластичних властивостей як шкіряного напівфабрикату, так і покриття.

Повна заміна екстракту квебрахо нанокремнеземом А-300 в композиції 3 акриловою дисперсією Retanal RCN-40 за технологією 3 супроводжується збільшенням вмісту жирувального реагенту в матеріалі порівняно 3 діючою технологією на 8-17\% (табл. 5). При цьому щільніша периферійна ділянка містить більше пластифікуючої речовини на $18,7 \%$. 
Таблиия 5. Фізико-хімічні властивості шкір світлих кольорів

\begin{tabular}{|c|c|c|}
\hline Показник & \multicolumn{2}{|c|}{ Топографічна ділянка } \\
\cline { 2 - 3 } & чепрак & пола \\
\hline Масова частка, \%: вологи & $12,8 / 13,0$ & $13,1 / 13,6$ \\
- золи & $9,5 / 5,1$ & $9,7 / 5,6$ \\
- оксиду хрому (III) & $3,6 / 3,8$ & $3,8 / 4,1$ \\
- оксид кремнію (IV) & $3,2 /-$ & $3,9 /-$ \\
Мечови & $9,5 / 8,1$ \\
Межа міцності при розтягуванні, МПа & $8,0 / 7,4$ & $17,0 / 15,2$ \\
Межа міцності лицьового шару, МПа & $20,4 / 19,0$ & $17,0 / 14,0$ \\
Відносне видовження при навантаженні 10МПа, \% & $32,8 / 17,4$ & $38,0 / 33,0$ \\
Відносне видовження при розриві, \% & $58,0 / 55,0$ & $64,0 / 60,0$ \\
Жорсткість шкіри, сН & $26,0 / 30,0$ & $24,0 / 27,0$ \\
\cline { 2 - 3 } Вихід площі, \% & \multicolumn{2}{|c|}{$103,7 / 100,0$} \\
\hline
\end{tabular}

Примітка. Наведені значення показників до і після похилої лінії належать дослідним і контрольним зразкам.

Аналіз фізико-механічних властивостей наповнених шкір світлого кольору свідчить про те, що за комплексом пружно-пластичних характеристик, у тому числі й за міцністю лицьового шару, зразки, отримані за дослідною технологією, перевищують контрольні. Особливо це стосується більших значень деформаційних показників. Причому цей ефект ефективніше виявляється у ділянці поли. Зменшення різниці між показниками поли і чепрака свідчить про підвищення рівномірності розподілу компонентів наповнювально-додублювальної композиції в об'ємі шкіри і підвищення ії однорідності структури та властивостей за топографічними ділянками. Підвищені еластичні властивості шкір, наповнених нанокремнезем-акриловою композицією, за розробленою технологією сприяють більшому виходу площі шкіри порівняно 3 виготовленими за діючою технологією.

Підвищена витрата покривної фарби на 33\% при формуванні покриття світлих кольорів на шкіряному напівфабрикаті, наповненому-додубленому без використання танідів (табл. 6), зумовлює підвищення товщини покриття на 9\%, але це практично не змінює фізико-механічні властивості покривної плівки. При цьому адгезійні показники покривної плівки, що характеризують iï зв'язок 3 шкіряним матеріалом, забезпечуються, в основному, складом грунту.

\section{Таблиия 6. Фізико-механічні властивості покриття білих шкір}

\begin{tabular}{|c|c|c|}
\hline Показник & \multicolumn{2}{|c|}{ Технологія } \\
\cline { 2 - 3 } & 3 & діюча \\
\hline Маса покривної плівки, г/м² & 80,26 & 73,7 \\
Адгезія покриття, Н/м, до сухої шкіри & 1075 & 880 \\
- до мокрої шкіри & 507 & 390 \\
Стійкість покриття до мокрого тертя, оберти & 320 & 320 \\
- до багаторазового вигинання, тис. вигинів & 19,5 & 18,5 \\
\hline
\end{tabular}

Слід відзначити зменшення різниці між показниками багаторазового вигинання покриття шкіряних матеріалів, виготовлених за розробленою і промис- 
ловою технологіями, що відповідає вимогам до еластичних шкір хромового дублення.

\section{Висновки}

1. Проведена промислова апробація розроблених технологій наповнювання-додублювання шкіряного напівфабрикату хромового дублення передбачає використання нанокремнезему А-300, скорочення витрат дефіцитних імпортних реагентів, попередню пластифікацію дубленого напівфабрикату, а також повну заміну реагентів, що забарвлюють шкіряний матеріал.

2. Зменшення витрат імпортних матеріалів завдяки використанню йонізованого нанокремнезему А-300 за технологією 1 забезпечує формування еластичного шкіряного матеріалу з підвищеними об'ємним виходом і адгезією, відповідно, на $13 \%$ і $19-26 \%$ порівняно з матеріалом, отриманим за діючою технологією.

3. Використання біокаталітичного модифікатора в технології 2 дало можливість скоротити витрати імпортних реагентів на $38 \%$ при підвищенні пружнопластичних показників шкіряного матеріалу, зокрема розривного видовження до $77 \%$. При цьому досягається збільшення виходу площі шкіряного матеріалу на $5,1 \%$.

4. Повна заміна екстракту квебрахо нанокремнеземом А-300 за технологією 3 забезпечує формування шкір світлих кольорів топографічно більш однорідних $з$ підвищенням виходу площі на 3,7\%.

5. За комплексом фізико-механічних властивостей шкіряні матеріали, отримані за розробленими технологіями, переважають шкіри, що виготовляються за промисловою технологією і відповідають вимогам щодо еластичних шкір для швейних виробів за ДСТУ 3115-95 та міжнародного стандарту ISO 9001:2015 «Системи управління якістю. Вимоги».

6. Виготовлення шкіряних матеріалів за розробленими технологіями формування еластичних шкіряних матеріалів хромового дублення патентообгрунтовані й можуть розглядатись як перспективні для впровадження на підприємствах шкіряного виробництва.

\section{Література}

1. Lakshmiarayana Y., Jaisankar S. N., Ramalingam S., Radakrishnan G. A novel water dispersible bentonite-acrylic graft copolymer as a filler cum retanning agent. J. Amer. Leather Chem. Assoc. 2002. Vol. 97, No 1. P. 14-22.

2. Mokrousova E., Dzyazko Y., Volfkovich Y., Nikolskaya N. Switzerland Nanophysics, Nanophotonics, Surface Studies, and Applications. Springer Proceeding in Physics: Hfrt IV. Nanochemistry and Biotechnology. 2016. Vol. 183. P. 277-290.

3. D`Aquino A., Barbani N., D`Elia G. et al. Combined organic tanning based on mimosa and oxazolidine: development of a semi-industrial scale process for high-qualiti bovine upper leather. SLTC. 2013. Vol. 1, No 1. P. 9-15.

4. Ma J. Z., Lu H. Elasticity studies on leather retanned with various types of acrylic polymers. J. Amer. Leather Chem. Assoc. 2008. Vol. 103, Issue 11. P. 363-369.

5. Taylor M. M., Lee J., Bumanlag L. P., Balada E. H., Brown E. M. Treatments to enhance properties of chrome-free (wet white) leather. J. Amer. Leather Chem. Assoc. 2011. Vol. 106. No 2. P. 35-43. 
6. Yan L., Luo Z., Fan H., Liu Y., Li H., Peng B., Shi B. Nano-SiO2 oxazolidine combination tannage: Potential for chrome-free leather. J. Amer. Leather Chem. Assoc. 2008. Vol. 92, No 6. P. 252-257.

7. Композиція для наповнення шкіряного напівфабрикату: пат. 116990 Україна. № 201613556; заявл, 29.12.2016; опубл. 12.06.2017, Бюл. 11.

8. Данилкович А.Г., Білінський О.С., Кудзієва А.Ю. Використання високодисперсного оксиду кремнію в технології виготовлення шкіряного напівфабрикату. Вісник ХНУ. Технічні науки. 2016. № 6. С. 112-116.

9. Danylkovych A. H., Bilinskiy S. O., Potach Yu. V. Plasticification of leather semifinished chrome tanning. EUREKA: Physics and engineering. 2018. No 1. P. 12-18.

10. Білінський С.О., Данилкович А.Г. Виготовлення шкір світлих кольорів 3 напівфабрикату хромового дублення. Вісник ХНУ. Технічні науки. 2018. № 4. С. 102-107.

11. Варбанець Л.Д., Авдіюк К.В., Борзова Н. В. Мікробні $\alpha$-амілази: виділення, властивості, практичне застосування [Електронний ресурc]. URL: http://nbuv.gov.ua/UJRN/biot_2008_1_2_6 (дата звернення: 21.10.2017).

12. Данилкович А.Г., Чурсин В.И. Аналитический контроль в производстве кожи и меха. Лабораторный практикум : учеб. пособие. Москва: НИЦ Инфра-М, 2016. 176 с. 